Yuliana Dunayevska MA, Philology;

Serhii Sushko, Assist. Prof. Kramatorsk Institute, Private Joint-Stock Company «"Higher Education Institution" Interregional Academy of Personnel Management»

gzmk inpp@lp.edu.ua

\title{
THE DICHOTOMY OF THE' MANIPULATIVE VERSUS COUNTER- MANIPULATIVE IMPACT': DOES IT EXIST IN THE ENGLISH- WRITTEN MASS MEDIA TEXTS ON CLIMATE CHANGE?
}

\author{
(C) Dunayevska Yuliana, Sushko Serhii, 2018
}

Problem .For all the undisputable good that mass media have afforded the society, they are as well known to be exploiting on a high scale the means of manipulation which results in the public being deceived or told half-truth, information distorted, an individual recipient misled. Elucidating the means and markers of manipulation in a media text constitutes a formidable problem of media linguistics. It cannot be otherwise because it is the nature of manipulation to hide the means of its impact. Once a particular text is said to be manipulative then there must exist its counterpart which is not manipulative and which primarily aims at exposing the manipulative techniques and devices of the text claimed to be intentionally biased and falsified. The twofold problem arises in this respect: how to track down a manipulative text and be sure that some other text is not manipulative, and how to expose, or bring to light, the manipulative techniques and devices in the text claimed to be manipulative. The purpose of this research is to suggest a principle of a pairwise text according to which two mutually opposed texts should be treated based on what is said and claimed in either of them, but not proceeding from the label attached to either of them in advance. The next purpose, which we find more important and more instrumental than the first one, is to work out the ways of applying the «seven common propaganda devices», compiled by the American «Institute for Propaganda Analysis» in the previous century, - and their extended modifications - to the process of specifying the forms and means of manipulation in the climate change texts. We made use of the following methods: data collection methods - observation, survey, textual and content analysis, classification; qualitative and quantitative analysis; theoretical construction method. Also applied were the following features of the discourse analysis and critical discourse analysis methods: interpretive repertoire, language as social practice, text and context, interdiscursivity / intertextuality, The results obtained show that the climate change texts written by climate deniers (an adopted term in the media and scholarly discourse) display a great amount and variety of manipulative means as compared with climate science texts, the latter group of texts not being entirely free of the manipulative devices used. We may assume that originality aspects of this paper are in (1) an approach to compare largely antagonistic articles on the scope and variety of the manipulative features employed, (2) proving an instrumental character of the seven-item list of «common propaganda devices» for detecting manipulation techniques, (3) suggesting a taxonomy of the media texts highlighting the climate change issues. Conclusions. In this paper it has been ascertained that the manipulative discourse is predominant in the climate denier texts whereas climate science media texts feature it on a much lesser scale. The controversy of views on and proposed solutions of climate change problems reflects itself in the dichotomy-broken media texts on the said problems. At the same time, there is a clear tendency of there appearing more and more texts which do not belong to either side of the dichotomous division but offer other 
ways of tackling the said problems, the problem of removing confrontation of the science and public included. We believe the science of media linguistics is still in need of developing further a set of instruments to undisguisethe means of manipulating in the sphere of climate change. Teun van Dijk's method of triangulating a problem being manipulated into ... is exemplary on the way of elaborating a procedure of telling a manipulative text from a non-manipulative one.

Keywords: manipulative, discourse, mass media, media text, climate change, global warming, triangulation, consensus gap, research, climate change denier, propaganda devices, article, blog, proxy, pairwise texts

Юліана Дунаєвська, Сергій Сушко

\section{ДИХОТОМІЯ «МАНІПУЛЯТИВНИЙ - КОНТРМАНІПУЛЯТИВНИЙ ВПЛИВ»: ЧИ ІСНУЄ ВОНА В АНГЛІЙСЬКОМОВНИХ МЕДІАТЕКСТАХ 3 ТЕМАТИКИ ЗМІН КЛІМАТУ?}

Розглянуто складну проблему медіалінгвістики, яку утворюе завдання виокремлення засобів і ознак маніпулятивності у медіатексті. Якщо певний текст вважається маніпулятивним, тоді має існувати протилежний йому текст, у загальному сенсі, який не є маніпулятивним і який головно спрямований на викриття маніпулятивних прийомів тексту, якому інкримінують навмисно викривлене подання інформації. Англійськомовний дискурс 3 тематики зміни клімату демонструс значний обсяг текстів, які позиціонують себе до одного чи іншого типу, або їх зараховують опоненти до певного типу. Як актуальну дослідницьку проблему розглядаємо засоби маніпулятивного впливу у текстах, створених тими, хто заперечус зміну клімату, а також виокремлення цих засобів у текстах їхніх опонентів, прибічників наукової концепції зміни клімату, які утворюють переважну наукову спільноту. Встановлено, що неозорий корпус текстів, що висвітлюють зміну клімату, розподілясться переважно на дві протилежні множини. Лінія розподілу між ними проходить у площині наявності чи відсутності маніпулятивних засобів і ознак у тексті. Тому є підстави вважати наявною дихотомію маніпулятивного i контрманіпулятивного впливу в англійськомовних текстах зазначеної тематики. У зв'язку з гостротою проблеми протистояння у сфері бачення проблеми зміни клімату та способів їі висвітлення у ЗМІ актуальною є проблема подальшої розробки процедур і алгоритму виокремлення засобів маніпулятивності у медіатексті.

Ключові слова: маніпулятивний, дискурс, ЗМІ, зміна клімату, глобальне потепління, тріангуляція, конфлікт стосовно консенсусу, наукове дослідження, «заперечувальник» зміни клімату, пропагандистські прийоми, стаття, блог, проксі / репрезентант, попарні тексти.

Topicality of the problem raised is accounted by the top most relevance of the phenomenon of climate change, or global warming, for the mankind. The challenges of gradual worsening of the climate for us, people inhabiting our planet and countless species of other organic life, are enormous unless the humanity takes resolute and consolidated steps to reverse the negative changes of the climate. The problem of coverage of this phenomenon in mass media has never lost its acuteness in view of radically opposed opinions of, and attitudes to the climate change. The society in its accumulation of public institutions and a myriad of personal views has divided broadly into two hostile camps, that of advocating for prompt and severe steps to be taken to curb and reverse global warming, and the one which has long been downgrading the scientific results and findings of the «alarmists». This second camp got an equally insulting nickname, that of «deniers», «climate deniers». Their confrontation, if not an open verbal fight, is strikingly marked for a wide use of manipulative techniques which are aimed at distorting the truth about climate change issues. It is therefore quite topical to unravel deliberate falsehoods and spot down and define these techniques to avoid 'being fooled' on the said issues. 
Setting the problem.We put forward a working hypothesis of there being a principal watershed between allegedly manipulative texts on the climate change issues and those texts which expose the texture of manipulative techniques, devices and technologies in the texts of the former kind. We term the texts of the second kind «counter-manipulative texts». Our principal contention is that both manipulative and countermanipulative means in a media text cannot be reduced to linguistic, verbal means only. Manipulation and falsification, or manipulators and falsifiers, effectively use other mechanisms of swaying a recipient's mind in a desired direction as well - by way of using the old and better known methods and techniques, and by actively exploiting the newer forms of manipulation like agenda setting, spin doctoring, think tanks, cherry picking, keystone domino strategy, Serengeti strategy, «backfire effect» and others.

The significance of the research, the results of which we present in this article, proceeds from an obviously relentless confrontation between the proponents of the climate change theory who insist on the crucial role of the anthropogenic factor in the global warming and their numerous and influential opponents who deny, reject, doubt, criticize the said theory, and, to a large extent, accuse the proponents of the said theory in attaching undue urgency to it, and even in manipulating the relevant research thus misleading the public.

The latest research of the problem of manipulative featuring of the climate change phenomenon and related issues can be broken into several tiers, or vectors. The first research vector falls on the academic studies, books in which a variegated range of the means of manipulation of the climate change issues is thoroughly treated. It is represented by such titles as: Climate change denial. Sources, actors and strategies by Riley E. Dunlapand Aaron M. McCright(2010), Sociological Perspectives, edited by Riley E. Dunlap and Robert J. Brulle (2015), Why we disagree about climate change: understanding controversy, inaction and opportunity by Mike Hulme (2009), Climate Change Denial: Heads in the Sand, coauthored by Haydn Washington and John Cook (2011). This list of the books exposing the climate denier views extends to dozens of titles and continues to grow.

The second, largest, vector represents an innumerable range of current media texts which deal with a vast host of manipulative techniques and devices claimed to be used in reporting and featuring the global climate change. Illustrative of this range are prolific publications by Riley E. Dunlap, like Challenging Climate Change: The Denial Countermovement co-authored with Aaron M. McCright, Sharon Begley's The Truth About Denial, David McKnight's A change in the climate? The journalism of opinion at News Corporation.

The third vector is made up of a numerous range of publications which are aimed at reversing the situation with the «consensus gap», which prioritize instructing the public on the climate change issues by way of confrontation-free approach, by way of giving due consideration to the mindsets on both sides.

An indelible contribution into the theory of manipulation in mass media added by the practical application of the given theory for exposing discursive manipulation has been made by an outstanding scholar Teun van Dijk. He included into scientific use and circulation a number of terms, notions, ideas, interpretive formulae which are of great aid both for the scholar and the mass media recipient. Some of these are triangulating a social, cognitive and discursive approach, illegitimate manipulation and legitimate persuasion, victims of manipulation, abuse of power and domination as hidden motives of manipulation,

Innovative aspects of the research the results of which are presented in this paper are: (1) a comparative approach is suggested to largely antagonistic articles with the aim of finding out the scope and variety of the manipulative features employed, (2) application of the seven-item list of «common propaganda devices», and the given list's modifications, for detecting manipulation techniques, (3) a taxonomy of the media texts highlighting the climate change issues is suggested which extends the duality of the types of climate change texts.

Objective of the given research. For all the difference of views on the nature and structure of the verbal manipulate on, one can hardly doubt its basic purport of hiding a true aim of the message conveyed as contrasted to the proclaimed one. A very intricate problem arises in this respect. Namely how to expose, to 
lay bare this hidden aim? One thing is to have at a ready disposal scores of identified and well-explained means and devices of manipulation of facts, faiths, concepts, notions, beliefs and values - and quite another thing is to specify and expose a multitude of manipulation means in a particular media text in respect of which there are either claims or allegations of it being a manipulative product. Thus, our objective of the research undertaken is twofold: to examine a set of frequently and effectively used means of manipulation in the Anglo-American segment of mass media dealing with the climate change, a mega problem facing the mankind, and, secondly, to draw a principal difference between obviously, or not so obviously, manipulative media texts on the given subject and those which expose them, which belong to the register of investigative journalism. We define the articles which can be ascertained as free from manipulative techniques as countermanipulative media texts.

Tasks of the research undertaken: to read and numerous articles and papers devoted to climate change to get some working knowledge of the problem; to study the relevant professional literature on manipulation in press and, wider, in mass media; to select a number of climate change media texts for analysis of manipulative means; to apply the seven-item list of «common propaganda devices», and their newer extended modifications, to a particular analysis of a particular text; to explore the multitude of climate change texts for other varieties which go beyond the dichotomy-bound division into mutually opposed texts.

The research results based on argumentation and analysis. The English discourse on the means of manipulative effect in the mass media has accumulated an impressive taxonomy of these means, a number of classifications of manipulative devices, strategies and technologies. Some of these are ten-position lists of the devices elaborated and used for deceiving a media text recipient. One of them is a ten-item classificationthat puts into limelight some manipulative strategies employed by mass media: diverting the attention, creation of problems, gradual changes, procrastination, use of children language, awaking the emotion, ignorance, magnification of stupidity, creation of guiltfeeling, abuse of knowledge [6].

A well-known and still widely resorted to in research and mass media is the list of the «seven common propaganda devices» which was compiled by the American «Institute for Propaganda Analysis». The said Institute was set up in 1937 and functioned up to 1942. Already within the first year of its operation (Oct. 1937 - Oct. 1938) it published Volume I of its publications on propaganda analysis. In the Volume, the seven-item list of propaganda devices is elaborated, with a detailed explanation, and exemplification, of each item. What the authors of the Volume call propaganda falls easily, and aptly, into a category of manipulative means and technologies. In modern relevant research the notion 'propaganda' in the sense attached to it in the original Volume has promptly been transposed into the notion of 'manipulation' [see 1].

In the Volume, the concepts related to manipulation in press are so revealing and universal, that they have not lost their significance and topicality in modern research and media which specify and display an impressive array of new forms and kinds of manipulation. Plenty of formulations and explanations from the Volume are so succinct that they cannot fail to be quoted. In the Chapter «How to Detect Propaganda» the scholars explain: «WE ARE fooled by propaganda chiefly because we don't recognize it when we see it. ... We can more easily recognize propaganda when we see it if we are familiar with the seven common propaganda devices.» [1]. Giving the list of these devices, the authors explain further: «Why are we fooled by these devices? Because they appeal to our emotions rather than to our reason. They make us believe and do something we would not believe or do if we thought about it calmly, dispassionately. In examining these devices, note that they work most effectively at those times when we are too lazy to think for ourselves» [1].

The authors compiled the following seven-item list of «common propaganda devices»: 1) The Name Calling Device; 2) The Glittering Generalities Device; 3) The Transfer Device; 4) The Testimonial Device; 5) The Plain Folks Device; 6) The Card Stacking Device; 7) The Band Wagon Device.

This list served as a launching pad for making newer, more extended sets and classifications of manipulative means employed in the modern press. To analyze a variety of the articles on the topic of climate change for the manipulation markers we made use of a list of 15 positions compiled on the basis of 
the original seven-item list made by the American «Institute for Propaganda Analysis». We subjected an appreciable number of the climate-change publications to verification of applicability of these fifteen positions to each of them. One of the criteria to be trusted to refer an article to the manipulative text category was calling the article reviewed 'manipulative' already in the title of the opposing article.

The problem of an avalanche of manipulative media texts on the climate change has become it seems more acute in the recent years. This situation is acknowledged in the relevant professional discourse, it has been a subject-matter of a number of prominent publications. It has to be said to the credit of mass media institutions and organs that a practically equal space is given in press to the publications of opposing parties and camps concerning the climate change issues. Easily observable is a format of immediate response on the part of either side, be it alarmists or deniers, whenever an allegation of manipulation or political involvement is made. The mass media cannot live without sensational news, or without imparting sensational coloring even to the matters of serious concern, and the featuring of climate change issues makes no exception in this respect.

An essential component of the sensational covering of the climate change issues is a debate brought to life by a particularly poignant, or, even worse, outwardly reasonable but inwardly ill-meant and intricately manipulative 'voicing of an opinion' in press. We shall briefly outline here two such instances bearing in mind the task of treating manipulation aspects in a mass media text. Stephens was just appointed to be the Opinion column editor of the newspaper and it was his first entry into the column. It got an immediate and crushing rebuffin Susan Mathews' response article «Bret Stephens' First Column for the New York Times Is Classic Climate Change Denialism» published on the site www.slate.com. Only in the second half of his article, structured as an opinion, does Bret Stephens come up to the climate change issue properly. The first half he devotes to cultivating uncertainty to the so-called one hundred per cent truths. The journalist quotes slanderous language (from Czeslaw Milosz's Captive Mind) which is still normative and can therefore be quoted, «Whoever says he's 100 percent right is a fanatic, a thug, and the worst kind of rascal.» [5]. It is on this polemically sharpened phrase that Stephens builds up his essay which puts the climate science in distrust.

Susan Mathew has not failed to track down this leading motive of Stephens' article and she proceeds to undisguise it step by step, often empowering herself to 'read' Stephens' mind. Which is not quite convincing in itself and may cause the so-called «backfire effect». What we mean is the following over-assertive language of the journalist: Bret Stephens «is sowing the seeds of epistemicun certainty». «Trust nothing, heurges, for nothing deserves trust», «You have to bean idiotoraze a lot to believe climate change is certain, whispers the subtext». This language does not fully allow to treat Mathew's article as purely countermanipulative, or fully conforming to the register of legitimate persuasion texts. But her articleperfectly fits into the category of the dichotomy-broken texts, the authoress reveals Stephens' hidden, covetous intention as follows: «He cast shimself as a translator between the skeptics and the believers; ...From one angle, his point is quite familiar - it's actually one that has been made some what frequently lately, and by liberal leaningoutlets, too:

Shoving the certainty of fact down is not the way to get them to change the irminds, and it's high time we try something else» [3].

In keeping with our idea of pairwise texts we have examined both on the means of manipulative and counter-manipulative effect in them. We have arranged our findings in the Table form.

Manipulative means in B. Stephens” "Climate of Complete Certainty».

1. The play of meanings in the title

2. Means of manipulative effect:

a) «Reference to experts»

b) «Imagined choice»-

Perhaps if there had been less certitude and moresecond-guessing in Clinton's campaign,

she'd be president.
Means of exposing and downgrading the manipulative effect of Stephens' article in S. Mathews' response article:

1. Invective in the title

2. Means of counter-manipulative effect:

a) quoting the opponent to disprove his arguments

b) formulating the opponent's key arguments for him

c) 'trackingdown' the opponent's position to a certain group of views

d) Refutation and unraveling of the opponent's key theses 
c) «Method of negative groups of reference»Claiming total certainty about the science traduces the spirit of science and creates openings for doubt whenever a climate claim

proveswrong.

d) «One'sownguys» or «plain folks game»-

But ordinary citizens also have a right to

beskepticalof an overweening scientism.

e) «Emotional fitting»-

With me so far? Good. Let's turn to climate change.

f) «Card stacking device» -

Despite 30 years of efforts by scientists, politicians and activists to raise the alarm, nearly two-thirds of Americans are either indifferent to or only somewhat bothered by the prospect of planetary calamity.

g) «All common sense folks understand ...»-

Why? The science is settled. The threat is clear. ... Isn't this one instance, at least, where 100 percent of the truth resides on one side of the argument? e) defining the opponent's manipulative devices, or i n $\mathrm{t}$ e $\mathrm{n} \mathrm{t}$ i o n s, as they are seen by the opponent's critic

3. Linguistic means of manipulative impact:

- expressive and professional vocabulary - stylistic means :

a dog whistle, «The final shoe drop sin the last lines of the piece», «Shoving the certainty of fact down people's throats»,

- graphic means

- realia: a climate-change denier,

liberal-leaning outlets

4. Extra-linguistic means of impact:

- crisscross links

- author's views and argumentation

- quoting experts

- contextual / subtextual appeal to the recipient

As can be seen from the Table, we did not find any spectacular manipulative device in Susan Mathew's article despite the emotionally-charged tone of her response.

The second instance of sensational covering of the topic of climate change is easily supplied by another pair of related articles whose relationship can be characterized by the formula «exposure - reversed exposure / counter-exposure». In this case the sensation was unleashed with publication in The Mail on Sunday of the article by David Rose «Exposed: How world leaders were duped into investing billions over manipulated global warming data» (Feb. 4, 2017) [4]. It was immediately, on the second day, responded by Bob Ward who laid out his counter-arguments in «Morefakenewsin 'TheMailonSunday'». [8]. Bob Ward is a competent researcher in the climate research, he ispolicy and communications director at the Grantham Research Institute on Climate Change and the Environment at the London School of Economics and Political Science. Ward also compiled «A list of 30 false claims in the article by $\mathrm{Mr}$ Rose and the leading article that accompanied it» which he submitted to the Independent Press Standards Organization. His appeal resulted in the IPSO ruling The Mail on Sunday to acknowledge the breach of standards and retract D. Rose's article.

In this particular case we can see how effectively the democratic principles of press operation can be implemented resulting in prevention of the spread of distorted information, whether intentionally or not intentionally distorted.

Guided by a practically overall claim on the part of climate change researchers, who responded to Rose's sensational publication, that the latter, for all its fact file to the contrary, still was a pre-fabricated product aimed at discrediting the climate change science, we verified the given article for manipulative markers.

\begin{tabular}{|c|c|}
\hline $\begin{array}{l}\text { David Rose. «Exposed: How world leaders were } \\
\text { duped into investing billions over manipulated global } \\
\text { warming data» }\end{array}$ & $\begin{array}{l}\text { Bob Ward. «More fake news in 'The Mail on } \\
\text { Sunday'» }\end{array}$ \\
\hline $\begin{array}{l}\text { 1. «Imagined choice» - Has there been an } \\
\text { unexpected pause in global warming? If so, is the world } \\
\text { less sensitive to carbon dioxide than climate computer } \\
\text { models suggest? }\end{array}$ & $\begin{array}{l}\text { 1. Unequivocal title - } \text { "More fake news in 'The } \\
\text { Mail on Sunday'». } \\
\text { 2. Use of accusation formulae aimed at exposing } \\
\text { the opponent's incompetence and the tactics of distortion: }\end{array}$ \\
\hline $\begin{array}{l}\text { 2. «The Method of Negative Groups of } \\
\text { Reference»- } \\
\text { His vehement objections to the publication of the }\end{array}$ & $\begin{array}{l}\text { Are for publishing misleading (at best) climate- } \\
\text { related articles; have recently struck again; This } \\
\text { assertioni sentirely fabricated, misleading claims, }\end{array}$ \\
\hline
\end{tabular}


faulty data were overridden by his NOAA superiors in what he describes as a 'blatant attempt to intensify the impact' of what became known as the Pausebuster paper.

3. «Promotion through Mediators»-

Dr Bates said: 'They had good data from buoys. And they threw it out and «corrected» it by using the bad data from ships.

4. «Initiation of Information Wave»-

But the whistleblower, Dr John Bates, a top NOAA scientist with an impeccable reputation, has shown The Mail on Sunday irrefutable evidence ...

5. «The Card Stacking Device» - the totality of only negative facts

6. «The Name Calling Device»-weredupedinto, ClimateGate 2

7. Linguistic means of manipulative impact:

a) astonishing evidence, whistleblower, the 'pause'or 'slowdown', with a public relations fanfare, wass plashed across, vehement objections, hammered out the Paris Agreement, were flagrantly ignored, a blockbuster report,

b) scientific vocabulary, terms: seadataset, ERSSTv4, 'alpha' versionofthe

data, Argo,

c) stylistically expressive means: took the se uncertaintieson board, They played fast and loose with the figures,

d) realia: IPSO, NOAA, 'Pausebuster' paper',the 'Climategate' affair,

f)graphic means. simply incorrect, confuses, the claim ... was pre-bunked

3. Graphic means: global warming has not

slowed, global surface warming

4. Emotive, scientific, expressive lexicon and syntax:

virtually; attacking carbon pricing and investments in green energy; a long-term signal, timeframe,

HadCRUT4, the noise over this timeframe; was predictably reproduced uncritically, virtually every point, Were Rose and Curry Skeptical Science readers, it is entirely unsurprising

5. Allusions and realia:

«leading the witness»; trying to down the up escalator, 'Economics 101.'

Our search for the means of impact in both articles has produced the following results which we show in the Table form. In D. Rose's article, it is possible to refer some language and some factual material to the following manipulative devices. In Bob Ward's response article it is hard to specify any of the manipulative means which we have singled out in David Rose's article.

Limited and restricted as our range of competence in the 'disposition of forces' in the confrontation between alarmists and deniers is, it allows us to almost take for granted a long established viewpoint that it is deniers who are manipulators, not alarmists who are expected and believed not to serve any corporate or political interests. It is for this reason that the fact of an article belonging to an advocate of the climate change almost automatically renders it free of manipulation, and the other way round is true: once an article is written by a denier it is believed to be biased and manipulative.

Essentially for this reason Ward's article is rated as counter-manipulative whereas Rose's article is censured as manipulative and ill-purposed. But it is obvious that such general observation does not meet a demand of a proper verification of a particular article for the markers of manipulative discourse, or, in their place, the markers of legitimate persuasion. We have specified above some of the manipulative markers in Rose's article. It would be constructive and instrumental to specify the counter-manipulative aspects of Ward's article.

Quite an illustrative and instructive example of a set of manipulative devices and tactics on the part of the climate deniers is presented in an important research the results of which have been laid out in a scientific paper «Internet Blogs, Polar Bears, and Climate-Change Denial by Proxy» written by fourteen authors ((JeffreyAHarvey, DaphnevandenBerget al.) [2]. The electronic version of this paper integrates it undoubtedly into a media text because it has been expanded by two video recordings. These videos enhance a positive effect on a recipient due to the fact that some manipulative strategies of climate deniers are defined in them. 
The subject-matter of the paper is a so-called consensus gap. The term stands for a marked disparagein the views on the climate change on the part of the prevalent scientific community which forms the Consensus-97 majority and the popular public thought which tends to underestimate the serious implications of the climate change, if not doubt or ignore them. In particular, the paper treats a totality of the science-blog views on the problem of Arctic sea ice melting and the related problem of white bear survival, as well as the views on the same problems exposed in the climate denier blogosphere. The researchers have compared 45 science-based blogs and 45 denier blogs in their attitudes to the given problems and found out that the two groups of blogs held diametrically opposed positions in the frame of the «scientific uncertainty» in relation to the threat to the white bear population and their Arctic environment from the anthropogenic factor. The science-based blogs have provided convincing evidence of such a threat whereas denier blogs keep refuting it.

Examining and comparing confrontation of the opposing camps of views on the climate change, the authors of «Internet Blogs, Polar Bears, and Climate-Change Denial by Proxy» have also exposed some manipulative approaches and techniques resorted to by climate deniers. We have grouped them into a palette of some typical manipulative devices exploited in the climate denier discourse. The first device has to do with removing the context on the part of the climate deniers or flawed interpretation of the examples. The second device consists in selective observations isolated from the related context. This approach enables deniers to interpret observations in a biased focus contradicting or dwarfing the acute character of the climate change.The third device - which happens to be a 'patented' finding on the part of the paper authors - is a strategy of discrediting a proxy, a representative of the phenomenon of the anthropogenic global warming (AGW). If a popular notion of AGW is shown to be flawed, then the whole edifice of AGW is ruined like a long line of dominoes falls when a keystone domino has fallen. It is the extent of the Arctic ice and polar bears which are proxies for AGW and it is on them that climate deniers focus their campaign of doubt and denial. The fourth device may be defined as exploiting a self-entrusted competence in a particular field for which a person is not qualified. The fifth device consists in a manipulative selection of the in-between research results and qualifying them as contradictory. In this way, a frame of the science giving 'account' to society is getting actualized, the science is getting blamed for exaggerating its findings. There are some devices shown by the authors as manipulative on the part of those who got named as climate deniers,

This text which fits the categories of scientific papers and media texts we characterize as escaping the boundaries and certain excesses of the dichotomy-broken texts. It may be referred to the category of analytical articles with a retrospective component and educational components.

CONCLUSIONS. In the given paper, a research of the manipulative and counter-manipulative means in the media texts covering climate change and the related issues has been undertaken. Five original articles on the subject of climate change were selected and the relevant theoretical material was consulted to conduct the research. It has been ascertained that in the English discourse a vast mass of the climate change articles can be broken into two groups, the first one representing the climate change science supporters and advocates, and the second one manifesting the views and mindsets of those who disagree with the first group, who deny the climate change and the need for urgent steps to be taken to curb the disastrous climate changes.

In the process of specifying the manipulative and counter-manipulative means of impact in the climate change texts we have come upon such a cluster of texts which we have called pairwise texts. They are a pair of texts the second text of which is written as an immediate response to the earlier written one. As a rule, such pair manifests radically different views, the prior article and its author being blamed for manipulating the public by unfair means of deceit, distortion, playing on the set values.

In the paper, we have examined two such pairs of texts formanipulative and counter-manipulative means of impact in them. We have ascertained that the texts written by those who deny climate change, as well as a crucial role of the anthropogenic factor in it, tend to exploit manipulative devices on a regular if not permanent basis whereas the climate science texts feature a predominant use of what we call countermanipulative devices.

The analysis of the climate change texts in the English-written mass mediaproves the dichotomous division of the said texts into those packed with observant or non-observant manipulation means, and those which feature counter-manipulative means. An essential finding of this research is that the actual variety of the media texts on climate change exceeds the dichotomy-bound limitations and offers many texts of other conceptual type. 
The prospects of the research conducted are seen in: 1) elucidating a wider paradigm of manipulative means in a larger number of climate science and climate denial texts; 2) elaborating a system of markers and features of a counter-manipulative text; 3 ) working out a model of comparing the two texts in a pairwise text; 4) studying a series of the texts on climate change written by one author; 5) working out a taxonomy of the types of texts written on the subject of climate change.

\section{REFERENCES}

1. Analysis of the latest research and publications.Formulating of the article's oblective // Institute for Propaganda Analysis. Propaganda Analysis: Volume I of the Publications of the Institute for Propaganda Analysis, Inc. with New Materials to Aid Student and Adult Groups in the Analysis of Today's Propaganda. October, 1937 to October, 1938. New York: Institute for Propaganda Analysis, Inc. [Electronic resource]. Mode of access: https://archive.org/details/IPAVoll. 2.Jeffrey A Harvey, Daphne van den Berg, JacinthaEllers, RemkoKampen, Thomas W Crowther, Peter Roessingh, Bart Verheggen, Rascha J M Nuijten, Eric Post, Stephan Lewandowsky, Ian Stirling, MeenaBalgopal, Steven C Amstrup, Michael E Mann; Internet Blogs, Polar Bears, and Climate-Change Denial by Proxy, BioScience, Volume 68, Issue 4, 1 April 2018, Pages 281-287. [Electronic resource]. - Mode of access: https://doi.org/10.1093/biosci/bix133 3. Matthews S. Bret Stephens' First Column for the New York Times Is Classic Climate Change Denialism[Electronic resource] / Susan Matthews // Slate. - 2017.- Mode of access: http://www.slate.com/articles/health_and_science/science/2017/04/bret_stephens_first_new_york_

times_column_is_classic_climate_change_denialism.html. 4. Rose, Davis. Exposed: How world leaders were duped into investing billions over manipulated global warming data [Electronic resource]. - 2017. - Mode of access: https://science.house.gov/news/in-the-news/exposed-how-world-leaders-were-duped-investingbillions-over-manipulated-global. 5. Stephens B. Climate of Complete Certainty [Electronic resource] / Bret Stephens // The New York Times. - 2017. - Mode of access: https://www.nytimes. com/2017/04/28/opinion/climate-of-complete-certainty.html?_r=1. 6. 10 Strategies for Manipulation of People Through Media [Electronic resource]. - Mode of access: http://www.biz-development.com/biz-news2012/12.5.10-strategies-of- manipulation-with-people-through-media.htm. 7. Van Dijk Teun A. Discourse and manipulation[Electronic resource] / Teun A. van Dijk // Discourse \& Society - 2006. - Mode of access: http://www.discourses.org/OldArticles/Discourse\%20and\%20manipulation.pdf. 8. Ward B. More fake news in 'The Mail on Sunday' [Electronic resource] / Bob Ward. - 2017. - Mode of access: http://www.lse.ac.uk/GranthamInstitute/news/more-fake-news-in-the-mail-on-sunday/ 